
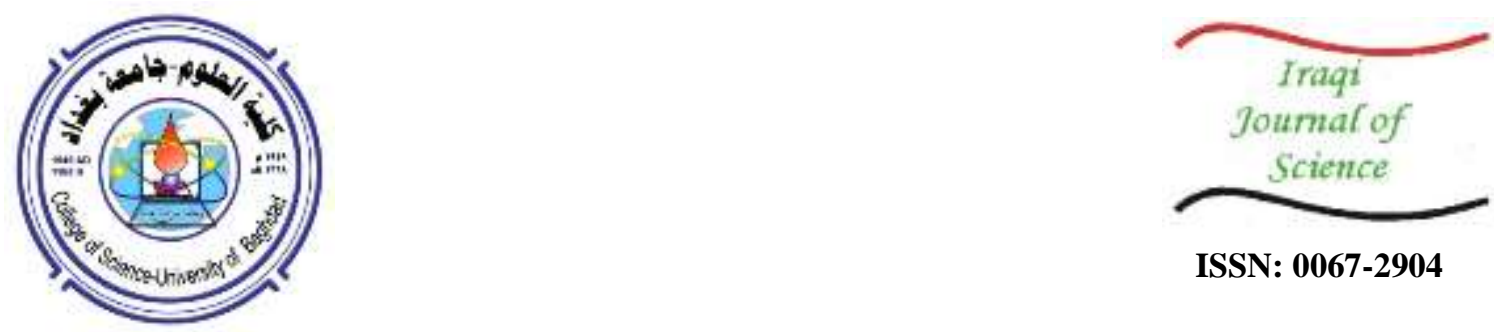

ISSN: 0067-2904

\title{
Heavy Metals Level Evaluation of Drinking Water Supply In Kirkuk City/NE of Iraq
}

\author{
Omer S. Al-Tamimi*, Sunbul Mustafa Anwar, Aseel Sharaf Abdullah
}

Environmental Research Unit, College of Science, University of Kirkuk, Kirkuk, Iraq

\begin{abstract}
An evaluation of pollution level has been done for drinking water which is used in Kirkuk city by heavy metals ( $\mathrm{As}, \mathrm{Cd}, \mathrm{Cu}, \mathrm{Fe}, \mathrm{Mn}, \mathrm{Ni}, \mathrm{Zn}, \mathrm{Cr}, \mathrm{Pb}$ ) samples were collected during wet and dry of 2016-2017 from Kirkuk unified water supplied project (WTP) which is supply the city with drinking water, as well as from water of tanks type (GST2), and also from (tap water) (Zone3). The results showed the concentration of the (As, $\mathrm{Cd}, \mathrm{Cu}, \mathrm{Fe}, \mathrm{Mn}, \mathrm{Ni}, \mathrm{Zn}, \mathrm{Cr}, \mathrm{Pb}$ )inppbfor (WTP)are $(0.5,0.6,6.45,38,4.6,2.5,6537,0.58,1.4)(0.6,0.8,6.76,46,5.5,3.5,6675,1,2.4)$ for (GST) $(0.5,0.63,6.46,52.3,4.4,3.6,6550,0.6,2.5) \quad(0.60,0.7,6.78,63.7,6.7,3.7,6680,1.1,2.6)$ and for tap water are $(0.53,0.65,7.00,60.2,4.4,3.65,7200,0.8,2.7)(0.60,0.71,7.10$, $67.6,6.8,3.75,7320,0.9,2.75)$ for two seasons respectively the concentrations are within the allowed limits by WHO just $\mathrm{Zn}$ is exceed the allowed limits . the level of health risks were also assessed by using a number of indices (HQ)ing, (HQ) derm, (HI), (CR) ing (CR) derm for adult and children and for two seasons . (HI) value for $\mathrm{Zn}$ show health risks this high value of (HI) for $\mathrm{Zn}$ make water undrinkable.
\end{abstract}

Key words: Heavy metals, Drinking water pollution, (HI) Index, Kirkuk city,Iraq.

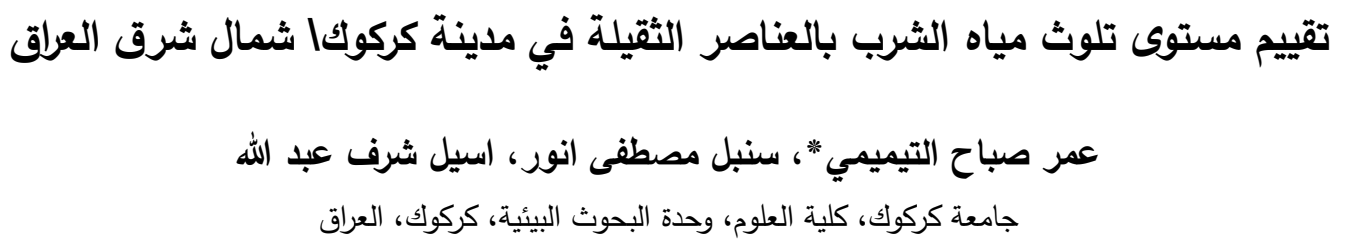

\footnotetext{
الخلاصة

تم في هذه الدراسة تقييم مستوى تلوث مياه الثرب في مدينة كركوك بالعناصر الثقيلة

التالية(AS,Cd,Cu,Fe,Mn,Ni,Zn,Cr,Pb) حيث تم جمع العينات خلال موسيمي صيف وشتاء (-2016 كياه

2017) من مشروع ماء كركوك الموحد (WTP) الذي يزود الدينة بمياه الثرب ومن خزانات المياه من نوع (AST)

0.5, 0.6, ومن مياه الاسالة ضمن المنطقة الثالثة (Zone3) وظهرت تراكيز العناصر كالتالئ (GST)

$0.5,0.63,6.46,52.3,4.4,3.6,6550,0.6$ ( 6.45, 38, 4.6 , 2.5, 6537, 0.58, 1.4

$0.6,0.8,6.76,46,5.5),(0.53,0.65,7.00,60.2,4.4,3.65,7200,0.8,2.7) \quad(, 2.5$

$0.60,0.71,7.10,) 0.60,0.7,6.78,63.7,6.7,3.7,6680,1.1,2.6)(3.5,6675,1,2.4$

(67.6, 6.8, 3.75, 7320, 0.9, 2.75

الحدود المسموح بها حسب منظمة الصحة العالمية (WHO) ماعدا عنصر الخارصين حيث تجاوز تركيزها

وللموسيمين الحدود المسموحة. تم دراسة مستوى المخاطر الصحية للهذه العناصر على الصغار وكبار

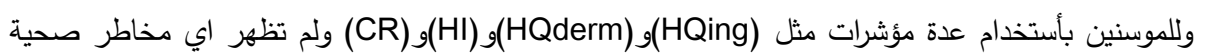




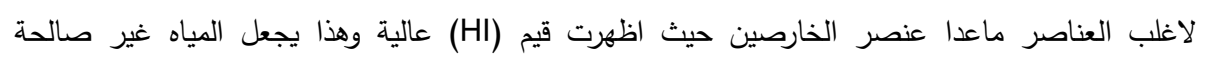

$$
\text { للشرب. }
$$

\section{Introduction}

Heavy metals are the general term encompassing the group of metals and non-metals which density is above $6 \mathrm{~g} / \mathrm{cm}^{3}[1,2]$ Trace elements may come from natural sources, leached from rocks and soil according to their geochemical mobility or come from anthropogenic sources like industrial discharge, urban runoff, sewage effluents[3]. Heavy metals presence in nature usually is not dangerous for the environment because they are present only in very small quantities and become polluted only if it's present in large quantities.. trace heavy metals analysis is an important part of public health studies [4], Some metals at trace levels in our metabolism are important for good health, but they become dangerous and toxic to human health if their concentrations rise from natural values, and cause many health risks like reduced growth, cancer, nervous system damage, and in extreme causes death. Drinking water contamination with heavy metals is one of the most important environmental issues as they are toxic even at low concentration [5].there are 23 of heavy metals: antimony, arsenic, chromium[6,7] gold, cerium, iron[8,9,10], platinum, cadmium[11,12] gallium, copper, bismuth, lead[13,14], manganese[15,16], silver, tellurium, thallium, tin, uranium, vanadium, nickel[17,18], mercury ,and zinc the most important of them is mercury, cadmium, lead, copper[19], iron, etc.,. The current study aims to assess the level of heavy metals contamination in drinking water in Kirkuk city and for the first time, there are no researches touched to study the heavy metals in drinking water for Kirkuk city.

\section{Study Area}

The study area (Kirkuk) city is located in the north eastern part of Iraq at cross of longitude $\left(35^{\circ} 2800^{\prime \prime}\right)$ and Latitude $\left(44^{0} 24 \cdot 00^{\prime \prime}\right)$. This study was conducted on drinking water that is used in this city , the samples were taken from Kirkuk unified water supply project include raw water (Lower Zab River), treated water (in side station)(WTP) . the samples is also taken from water tanks type (GST2) (five main tanks supplied water to the city represents by five zones), and also from tap water of some house in (Zone3) as shown Figure 1.

This project was designed with a production capacity about $(75,000) \mathrm{m}^{3} / \mathrm{h}$ which contain from the following units:[20]

A- (Low lift pumping station): This station is located on the Kirkuk irrigation canal and is far about $1 \mathrm{~km}$ from tap station the water is pulled from Irrigation canal that contains from the below units:

1- Suction well 2- Low lift pump

B- Water Treatment Plant: which contain of (1-Receiving well 2- Flash mixtures) 3(Clarifloculators): (16) circular basins every basin have (42m) diameter and $(9 \mathrm{~m})$ depth each basin contain two central basin internal basin for slow mixture(Sinter basin) external (sediment basin) that's water poured from this basin into a collection basin where chlorine is added as an initial stage before entering to filters.

4-(Filters): It is a type of quick (sand filters) that's work by gravity there where (80) filters that's water enter to it by (20) line of pipes every pipe connect to (4) filters, the capacity for each filter is about (5) $\mathrm{m}^{3} / \mathrm{m}^{2} / \mathrm{h}$ and the area is $(40) \mathrm{m}^{2}$. Chlorine was added to filtered water and water was discharged from each filter in about (200) $\mathrm{m}^{3} /$ hour.

5-(Ground tanks): two ground tanks the capacity for each one is (16000) $\mathrm{m}^{3}$ this tanks collect the water that's out from (Sterilization tank) before pumping water to the city by (high lift pumps)

6-(high lift pumping station): this station contains (7) pumps capacity for each one is (2520) $\mathrm{m}^{3} /$ hour, pressure load (40-80) $\mathrm{m}$, this pumps connect by two cities, of pipes diameter for each pipe is (1200) $\mathrm{mm}$ through this station water pumped to the city tanks type (GST). 


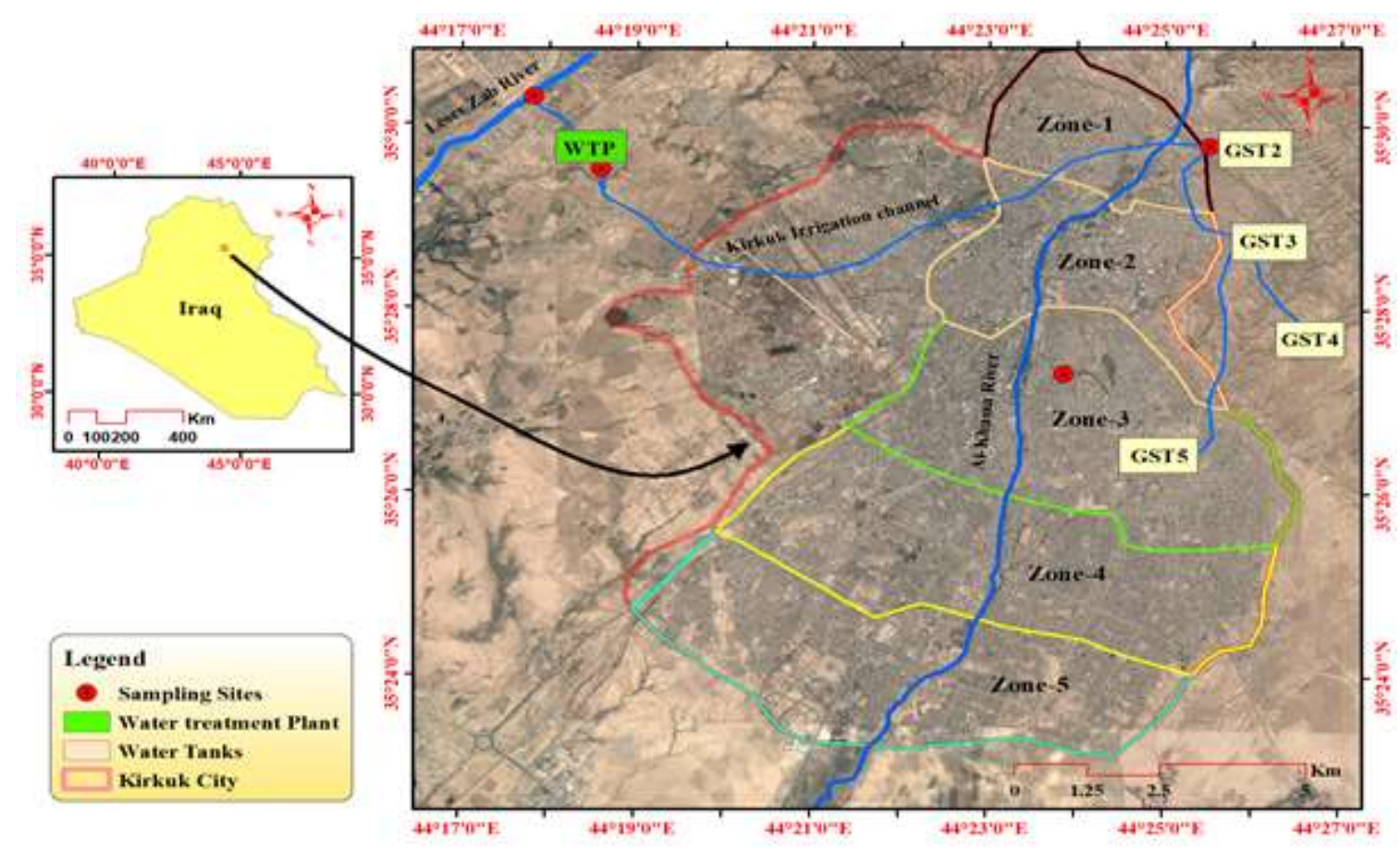

Figure 1-Location of Study Area

\section{Methodology}

4 water samples were collected from the study area included(Lower Zab river, treated water (WTP), the water of tanks(GST2), tap water (Zone3) in two seasons and stored in bottles type (polyethylene).pH, electrical conductivity (E.C), were measured in Kirkuk University environment research unit Laboratory. The samples filtered through pre-washed $(0.45 \mu \mathrm{m})$ nitrocellulose filters and acidify by using concentrated nitric acid to keep $\mathrm{pH}<2$ and storied at $-4^{0}$ to preserve the samples for accurate analysis of heavy metals [21]. The range of $(\mathrm{pH})$ and (E.C) values are (7.5-8.5) and (250-300) $\mu \mathrm{s} / \mathrm{cm}$ for two seasons (Wet-Dry) 2016-2017, And these values are within the allowed limits by WHO (6.5-8.5) for $\mathrm{pH}$, while for conductivity the organization did not specify the range [22][23]. The heavy metals concentrations were measured before and after treatment by using (Inductively Coupled Plasma Mass Spectrometry) technique in the (Bureau Veritas Mineral Laboratories - Vancouver Canada).

\section{Results and discussion}

The results of the current study show differences in the concentrations of selected heavy metals after treatment with chemicals and other mechanisms on which the station operates, the concentration of selected metals has become less than the concentration in raw water (before treatment) and this concentrations will not effect on human health because the results did not exceed the concentrations that permitted by WHO, just zinc exceed the allowed limits as shown in Table-1.

Table 1-Concentration of heavy metals before and after treatment in ( $\mathrm{ppb})$

\begin{tabular}{|c|c|c|c|c|c|c|}
\hline Metals & \multicolumn{2}{|c|}{ Lower zab river } & \multicolumn{2}{c|}{ Treated water } & WHO (2017) & USEPA(2017) \\
\hline Heavy metals & Wet & Dry & Wet & Dry & & \\
\hline $\mathrm{As}$ & 1.3 & 1.5 & 0.5 & 0.6 & 10 & 10 \\
\hline $\mathrm{Cd}$ & 5.3 & 6.5 & 0.6 & 0.8 & 3 & 5 \\
\hline $\mathrm{Cu}$ & 10.47 & 10.58 & 6.45 & 6.76 & 2000 & 1300 \\
\hline $\mathrm{Fe}$ & 59.1 & 72 & 38 & 46 & $<3000$ & $\ldots \ldots \ldots$ \\
\hline $\mathrm{Mn}$ & 6.3 & 7.7 & 4.6 & 5.5 & 400 & $\ldots \ldots \ldots$ \\
\hline $\mathrm{Ni}$ & 5.1 & 6.5 & 2.5 & 3.5 & 70 & $\ldots \ldots \ldots$ \\
\hline $\mathrm{Zn}$ & 21403.7 & 23916 & 6537 & 6675 & 3000 & $\ldots \ldots \ldots$ \\
\hline $\mathrm{Cr}$ & 1.2 & 1.5 & 0.58 & 1 & 50 & 100 \\
\hline $\mathrm{Pb}$ & 3.6 & 4.2 & 1.4 & 2.4 & 10 & 15 \\
\hline
\end{tabular}


in the Table- 2 the results showthe simple difference in the concentration of a specific element from one place to another within the area of interest (after treatment) in ppb included water of tanks type (GST) and tap water.

Table 2-concentration of heavy metals in water of tanks, tap water in (ppb)

\begin{tabular}{|c|c|c|c|c|c|c|}
\hline Metals & \multicolumn{2}{|c|}{ Water of tanks (GST) } & \multicolumn{2}{|c|}{ (Tap water ) } & WHO (2017) & USEPA(2017) \\
\hline Heavy metals & Wet & Dry & Wet & Dry & & \\
\hline $\mathrm{As}$ & 0.5 & 0.60 & 0.53 & 0.60 & 10 & 10 \\
\hline $\mathrm{Cd}$ & 0.63 & 0.7 & 0.65 & 0.71 & 30 & 5 \\
\hline $\mathrm{Cu}$ & 6.46 & 6.78 & 7.00 & 7.10 & 2000 & 1300 \\
\hline $\mathrm{Fe}$ & 52.3 & 63.7 & 60.2 & 67.6 & $<3000$ & $\ldots \ldots \ldots$ \\
\hline $\mathrm{Mn}$ & 4.4 & 6.7 & 4.4 & 6.8 & 400 & $\ldots \ldots \ldots$ \\
\hline $\mathrm{Ni}$ & 3.6 & 3.7 & 3.65 & 3.75 & 70 & $\ldots \ldots \ldots$ \\
\hline $\mathrm{Zn}$ & 6550 & 6680 & 7200 & 7320 & 3000 & 100 \\
\hline $\mathrm{Cr}$ & 0.6 & 1.1 & 0.8 & 0.9 & 50 & 15 \\
\hline $\mathrm{Pb}$ & 2.5 & 2.6 & 2.7 & 2.75 & 10 & $\ldots \ldots .$. \\
\hline
\end{tabular}

\section{Health Risk Assessment}

Risk assessment is a process which estimates the real or prospect reverse impact of contaminants to plants and animals and which condense on the disadvantage that has been or will be carried out by contaminants [24]. depending on the concentration of metals (non-carcinogenic risk) were assessed according to the exposure pathways of the previously recommended contaminants from(US environmental protection Agency). The potential water exposure pathways are direct water ingesting, and skin absorption of contaminants present in water. For calculation, the following equations were used [25].

$$
\begin{aligned}
& (\mathrm{ADD} \text { ing }=\mathrm{CW} * \mathrm{IR} * \mathrm{EF} * \mathrm{ED} /(\mathrm{BW} * \mathrm{AT}) \ldots) \\
& \left(\mathrm{ADD} \text { derm }=\mathrm{CW} * \mathrm{SA} * \mathrm{KP} * \mathrm{ET} * \mathrm{EF}^{*} \mathrm{ED} * \mathrm{CF} /(\mathrm{BW} * \mathrm{AT}) \ldots\right)
\end{aligned}
$$

Where ( $\mathrm{ADD}=$ Average Daily Dose by ingestion and dermal absorption (ADD derm), unit in $\mu \mathrm{g} / \mathrm{kg} /$ day), $(\mathrm{BW}=$ Average Body Weight ( $\mathrm{kg}, 70$ for adult and 15for children), (EF=Exposure Frequency(days/year, 350),(ED=Exposure Duration(years,30 for adult and 6 for children),(IR=Ingestion Rate(I/day, 2.2 for adults and 1.8 for children), $\mathrm{Cw}=$ concentration of the estimated metal in water $(\mu \mathrm{g} / \mathrm{L})$, (SA=exposed Skin Area $(\mathrm{cm} 2,18000$ for adult and 6600 for children),(KP=dermal permeability coefficient in water $\mathrm{cm} / \mathrm{h}$ ) (ET=Exposure Time(h/day, 0.85 for adult and 1 for children), (AT=Averaging Time(day, for non-carcinogenic ED*365 for carcinogenic $70 * 365$ for adult and children), (CF=unit Conversion Factor(L/cm3, 0.001).

Before a risk is described, hazard quotient (HQ) of each metal is calculated by using the following equation [26][27].

$$
(\mathrm{HQ}=\mathrm{ADD} / \mathrm{RFD})
$$

Where (HQ) is hazard Quotient via dermal or ingestion (unit less), RfD is Reference Dose via dermal or Ingestion in ( $\mu \mathrm{g} / \mathrm{kg} /$ day) (non-carcinogenic risk) if; $\mathrm{HQ}>1$ non-carcinogenic effects (concern). $\mathrm{HQ}<1$ accept level (no concern), (HI) value is $\Sigma \mathrm{HQ}_{\text {ing }}+\mathrm{HQ}_{\text {derm }}$ As for carcinogenic influence, Cancer risk was calculated by using the following equation [28]:

$$
\left(\mathrm{CR}=\mathrm{ADD}_{\text {ing }} * \mathrm{SF}\right),\left(\mathrm{CR}=\mathrm{ADD}_{\text {derm }} * \mathrm{SF}\right)
$$


( $\mathrm{SF}=$ oral carcinogenic slope of the contaminant $(\mathrm{mg} / \mathrm{kg} / \mathrm{day})$ for $\mathrm{Pb}=0.0085$, for $\mathrm{Cr}=0.05$ [25]. If $(\mathrm{CR})$ bigger than the range $10^{-4}-10^{-6}$ carcinogenic influence (concern) but if (CR) smaller than $10^{-4}-10^{-6}$ agreeable level (non-concern).[29]

$(\mathrm{HQ})_{\text {ing }}(\mathrm{HQ})_{\text {derm }}$, (HI) where calculated for water samples show in Tables- $(1,2)$ for two seasons (HQ) ing, (HQ) derm, (HI) values for, $\mathrm{Cd}, \mathrm{Cr}, \mathrm{Pb}, \mathrm{Cu}, \mathrm{Mn}, \mathrm{Fe}, \mathrm{As}$, $\mathrm{Ni}$ is less than (1) for adult and children. this is indicates the effect of water treatment that's induced the concentration of heavy metals in water also meaning there is no health risks (non-carcinogenic) (non-concern), as show in Figures-(2-9) and for dry season is higher than wet season this is a normal result due to water level decline in summer because of the lack of rainfall, which leads to deposition of elements deep in the water supply[29]. but (HQ) ing, (HQ)derm , (HI) for Zinc metal( $\mathrm{Zn})$ is higher than one before and after treatment this is may return to many factor like zinc known as one of the most element found in nature and there are many sources that's play to found this metal in high level like it's used in fungicides industries, detergents industries, drug industries because it has anti-bacterial properties which help to relieve stomach and bowel infections .[30][31] The study area is located within agricultural land where pesticides are used in large quantities, sewage water, and there are an oil production company within the same area.
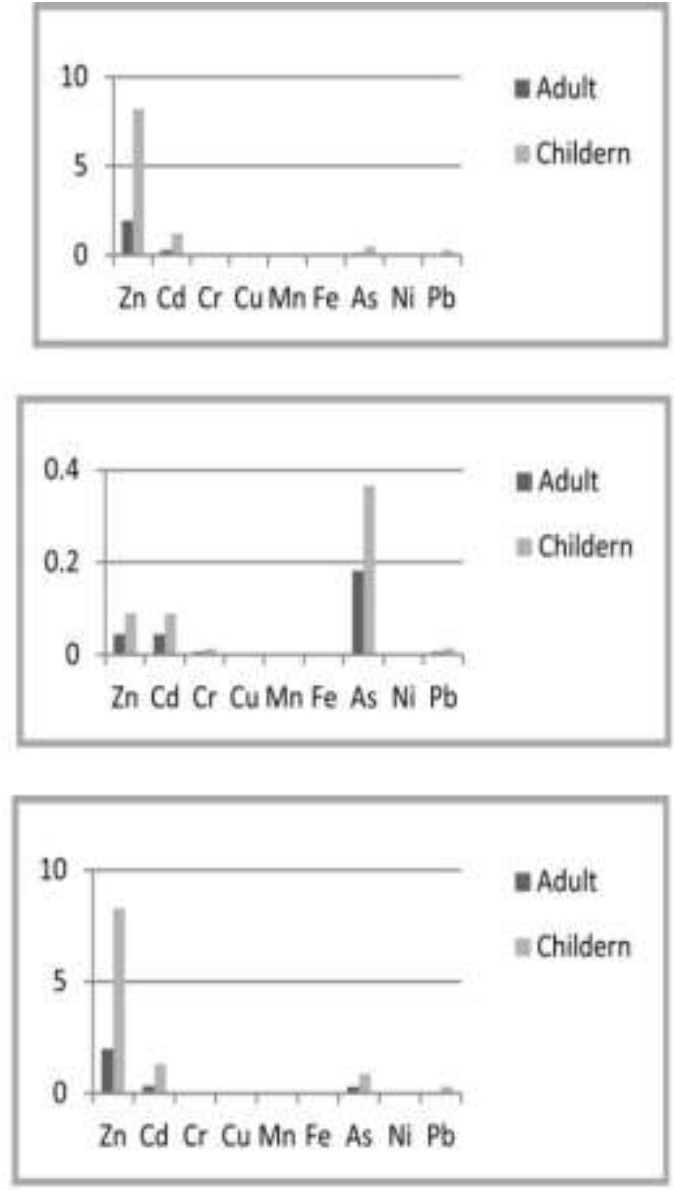

Figure 3-(HQ)ing, (HQ)derm, (HI) values in drinking water for adult and children in Lower Zab river (Wet)
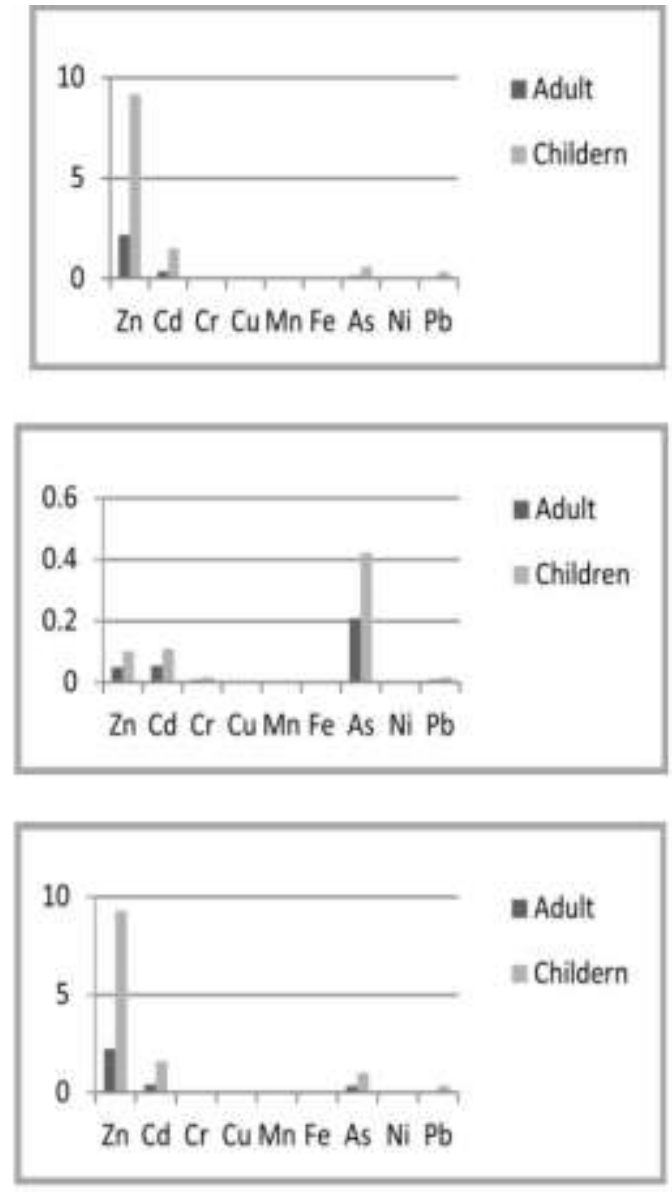

Figure 4-(HQ)ing, (HQ)derm, (HI) values in drinking water for adult and children in Lower Zab er (Dry) 

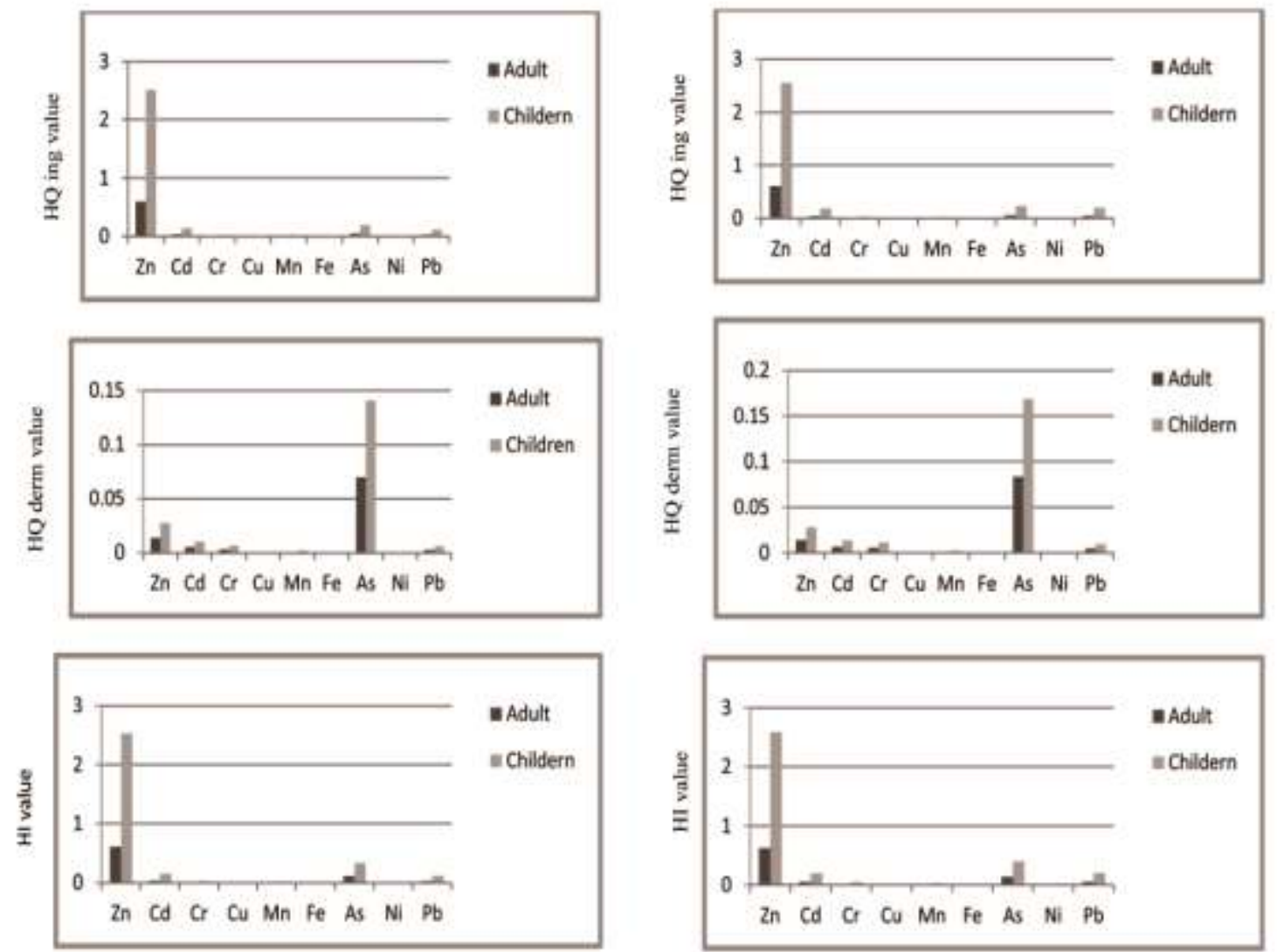

Figure (4): (HQ)ing, (HQ)derm, (HI) values in drinking water for adult and children in treatert water (wert)

Figure(5) (HQ) ing, (HQ) dem, (HI) values in drinking water for adult and childeren in trested water (Mru)
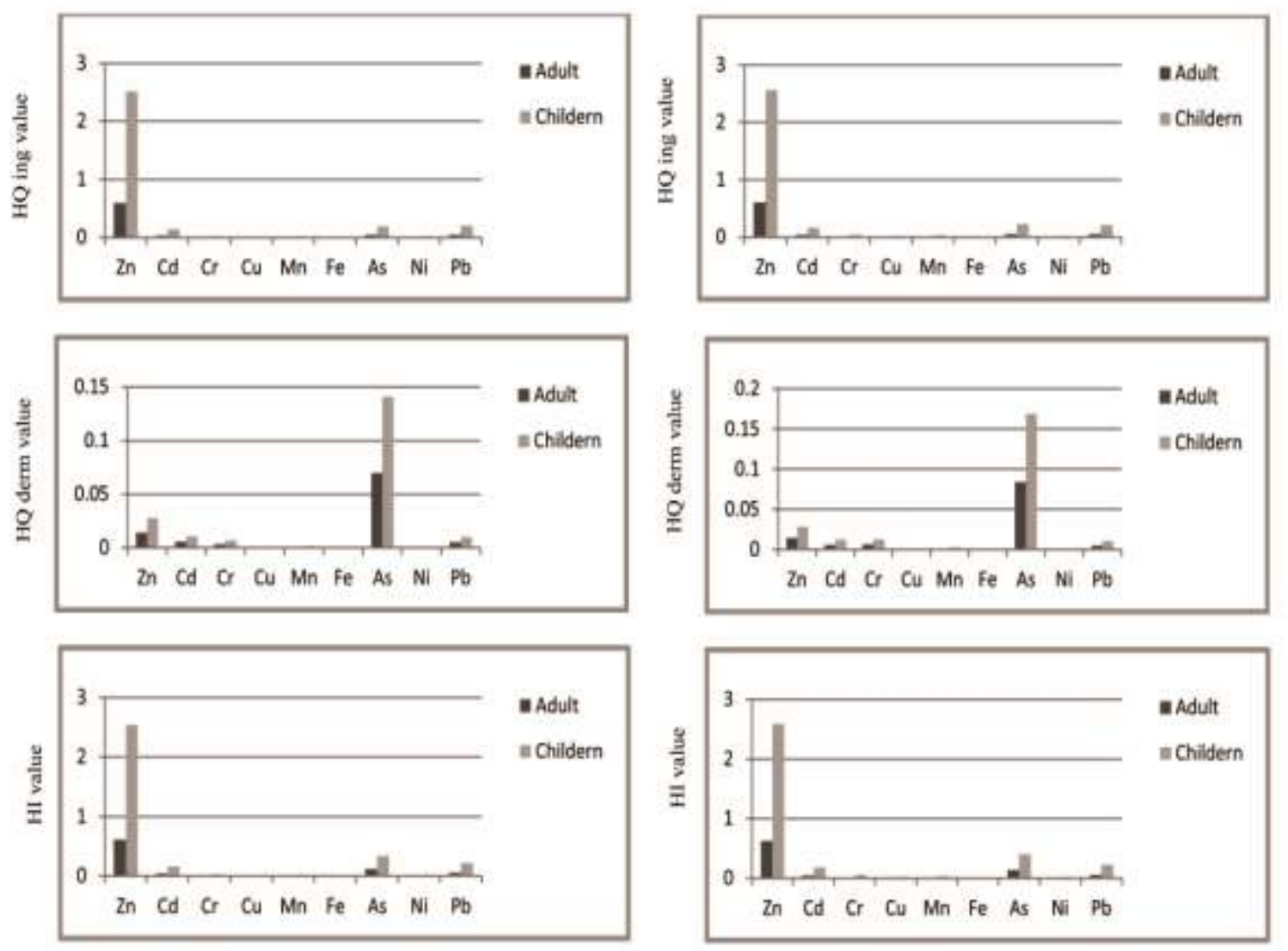

Figure(6) (HQ)ing. (HQ) derm, (HI) values in driaking water for adult and children in (water of tanks) (wet)

Figure(7) (HQ)ing, (HQ) derm, (HI) values in drinking water for adult and children in(water of tanks) (Dry) 

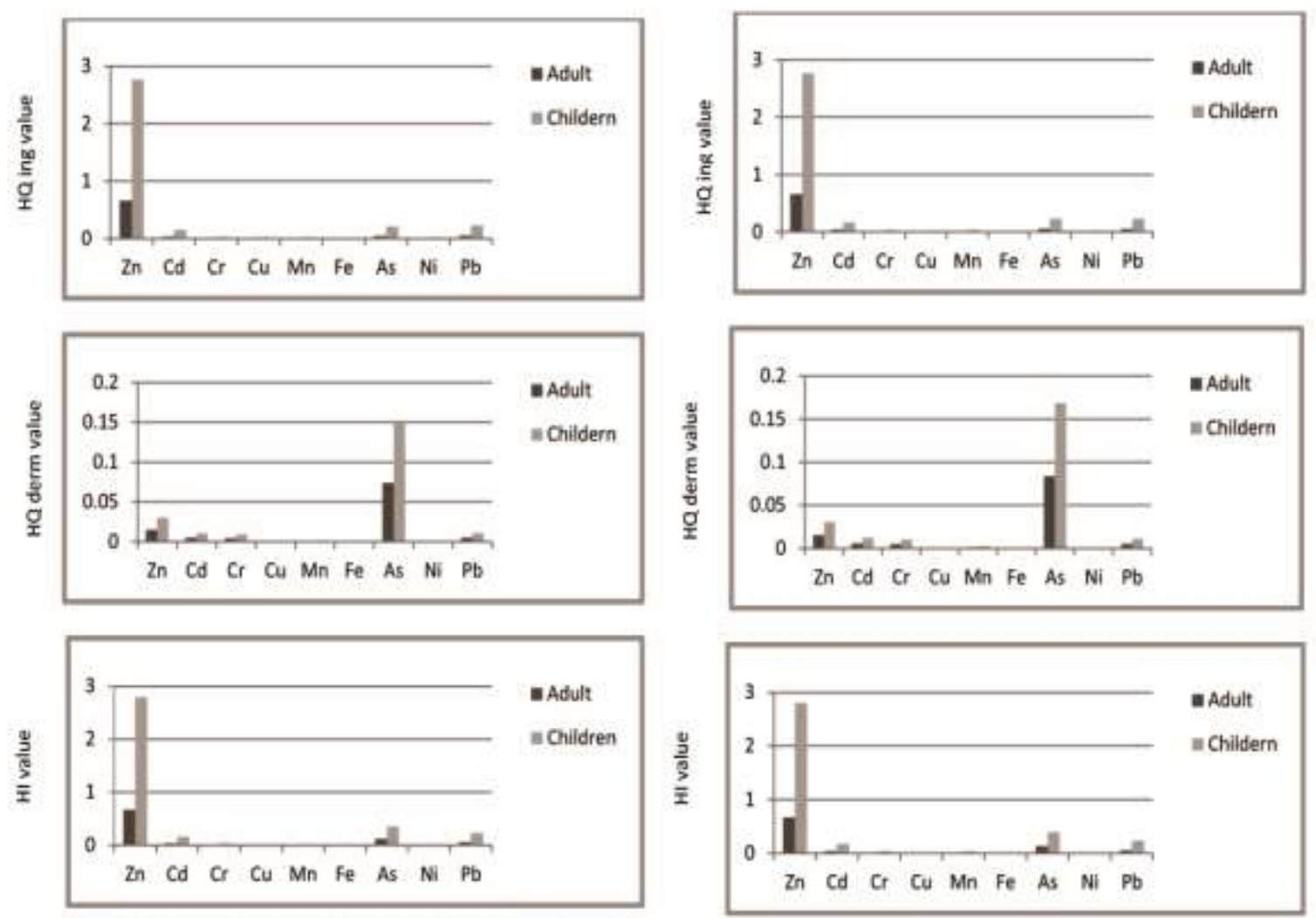

Figure (8) (HQ)ing (HQ)derm, (HI) values in drinking water for adult and children in' Tan water) (wet)

Figure (9) (HQ)ing, (HQ)derm, (HI) values in drinking water for adult and children in(Tapwater) (Dry)

Table-3 show carcinogenic risk(CR) for samples taken from Raw water (Lower Zab River), (treated water), (water of tanks) type (GST), (Tap water), (CR) ing $(\mathrm{CR})$ derm values for $(\mathrm{Pb})$ and $(\mathrm{Cr})$ in all samples for adult and children in two seasons not overtake the limits agreeable level (carcinogenic)(non- concern)

Table 3-A-Carcinogenic Hazards of heavy metals in Raw water (Lower zab river)

\begin{tabular}{|c|c|c|c|c|c|c|c|c|}
\hline Water & \multicolumn{4}{|c|}{ Raw water (Wet) } & \multicolumn{4}{|c|}{ Raw water (Dry) } \\
\hline & \multicolumn{2}{|c|}{$\mathrm{CR}$ ing } & \multicolumn{2}{|c|}{ CR derm } & \multicolumn{2}{|c|}{$\mathrm{CR}$ ing } & \multicolumn{2}{|c|}{ CR derm } \\
\hline $\begin{array}{l}\text { Heavy } \\
\text { metals }\end{array}$ & Adult & Children & Adult & Children & Adult & Children & Adult & Children \\
\hline $\mathrm{Pb}$ & $3.59 * 10^{-7}$ & $3.02 * 10^{-7}$ & $1.09 * 10^{-8}$ & $4.43 * 10^{-9}$ & $4.43 * 10^{-9}$ & $3.52 * 10^{-7}$ & $1.28 * 10^{-8}$ & $5.16^{*} 10^{-9}$ \\
\hline $\mathrm{Cr}$ & $7.05 * 10^{-7}$ & $5.92 * 10^{-7}$ & $1.08 * 10^{-8}$ & $4.34 * 10^{-9}$ & $8.81 * 10^{-7}$ & $7.39 * 10^{-7}$ & $1.35 * 10^{-8}$ & $5.42 * 10^{-9}$ \\
\hline
\end{tabular}


Table 3-B-Carcinogenic Hazards of heavy metals in Treated water

\begin{tabular}{|c|c|c|c|c|c|c|c|c|}
\hline Water & \multicolumn{4}{|c|}{ Treated water (Wet) } & \multicolumn{4}{|c|}{ Treated water (Dry) } \\
\hline & \multicolumn{2}{|c|}{ CR ing } & \multicolumn{2}{|c|}{ CR derm } & \multicolumn{2}{|c|}{$\mathrm{CR}$ ing } & \multicolumn{2}{|c|}{ CR derm } \\
\hline & Adult & Children & Adult & Children & Adult & Children & Adult & Children \\
\hline $\mathrm{Pb}$ & $1.39 * 10^{-7}$ & $1.17 * 10^{-7}$ & $4.28 * 10^{-9}$ & $1.72 * 10^{-9}$ & $1.72 * 10^{-9}$ & $2.01 * 10^{-7}$ & $7.33 * 10^{-8}$ & $2.95 * 10^{-9}$ \\
\hline $\mathrm{Cr}$ & $3.41 * 10^{-7}$ & $2.86 * 10^{-7}$ & $5.21 * 10^{-9}$ & $2.10 * 10^{-9}$ & $5.87 * 10^{-7}$ & $4.93 * 10^{-7}$ & $8.98 * 10^{-9}$ & $3.62 * 10^{-9}$ \\
\hline
\end{tabular}

Table 3-C-(Carcinogenic Hazards of heavy metals in (Water of tanks)

\begin{tabular}{|c|c|c|c|c|c|c|c|c|}
\hline $\begin{array}{c}\text { Water } \\
\text { Type }\end{array}$ & \multicolumn{3}{|c|}{ Water of tanks (Wet) } & \multicolumn{3}{c|}{ Water of tanks (Dry) } \\
\hline & \multicolumn{2}{|c|}{ CR ing } & \multicolumn{2}{c|}{ CR derm } & \multicolumn{2}{c|}{ CR ing } & \multicolumn{2}{c|}{ CR derm } \\
\hline $\begin{array}{c}\text { Heavy } \\
\text { metals }\end{array}$ & Adult & Children & Adult & Children & Adult & Children & Adult & Children \\
\hline $\mathrm{Pb}$ & $2.49 * 10^{-6}$ & $2.09 * 10^{-6}$ & $7.64 * 10^{-8}$ & $3.07 * 10^{-8}$ & $3.07 * 10^{-8}$ & $2.18^{*} 10^{-7}$ & $7.94 * 10^{-9}$ & $3.19^{*} 10^{-9}$ \\
\hline $\mathrm{Cr}$ & $3.5 * 10^{-7}$ & $2.96^{-9} 10^{-7}$ & $5.39 * 10^{-9}$ & $2.17 * 10^{-9}$ & $6.46^{*} 10^{-7}$ & $3.87 * 10^{-7}$ & $2.8^{*} 10^{-11}$ & $3.98^{*} 10^{-9}$ \\
\hline
\end{tabular}

Table 3-B-Carcinogenic Hazards of heavy metals in Tap water

\begin{tabular}{|c|c|c|c|c|c|c|c|c|}
\hline $\begin{array}{c}\text { Water } \\
\text { Type }\end{array}$ & \multicolumn{4}{|c|}{ Tap water (Wet) } & \multicolumn{3}{c|}{ Tap water (Dry) } \\
\hline & \multicolumn{2}{|c|}{ CR ing } & \multicolumn{2}{c|}{ CR derm } & \multicolumn{2}{c|}{ CR ing } & \multicolumn{2}{c|}{ CR derm } \\
\hline $\begin{array}{c}\text { Heavy } \\
\text { metal }\end{array}$ & Adult & Children & Adult & Children & Adult & Children & Adult & Children \\
\hline $\mathrm{Pb}$ & $2.69^{*} 10^{-7}$ & $2.26^{*} 10^{-7}$ & $8.25^{*} 10^{-9}$ & $3.32^{*} 10^{-9}$ & $3.32^{*} 10^{-9}$ & $2.31 * 10^{-7}$ & $8.39 * 10^{-9}$ & $3.38^{*} 10^{-9}$ \\
\hline $\mathrm{Cr}$ & $4.7 * 10^{-7}$ & $3.95^{-9} 10^{-7}$ & $7.19^{*} 10^{-9}$ & $2.90^{-9} 10^{-9}$ & $5.28^{*} 10^{-7}$ & $4.44^{*} 10^{-7}$ & $8.08^{*} 10^{-9}$ & $3.25^{*} 10^{-9}$ \\
\hline
\end{tabular}

\section{Conclusion}

After applied appropriate analysis by using modern technology it was found that drinking water in Kirkuk city was not contaminate with the following heavy metals ( $\mathrm{As}, \mathrm{Cd}, \mathrm{Cu}, \mathrm{Fe}, \mathrm{Mn}, \mathrm{Ni}, \mathrm{Pb}, \mathrm{Cr}$ ), the concentrations that obtained after analysis of samples that taken from Kirkuk unified water supplied project as well as from the main tanks and also from tap water, was not exceeding the permissible limits according to WHO, the level of health risks of these metals were also assessed on human health and showed no significant effect. All concentrations obtained were less than (1) for (HQ)ing, (HQ) derm and (HI) for As, Cd, Cu, Fe, Mn, Ni, Pb,Cr.but (HQ)ing, (HQ) derm, and (HI) for $\mathrm{Zn}$ is higher than(1) and the little change in concentration for ( $\mathrm{Zn})$ return to the precipitations processes that's used in (WTP) but is not enough so we need to use aspecial units in (WTP) for heavy metals treatment.The carcinogenic hazards show no health risks for selected metals $(\mathrm{Pb})$ and $(\mathrm{Cr})$

\section{Recommendations}

1- Installation special and periodic monitoring units within (WTP) to measure the concentration of heavy metals with electronic save for outputs.

2- Connect a warning system on (WTP) shut down when the concentration of heavy metals exceeded the permissible limits.

3- Using nanomaterial's to treat drinking water because the big enormous potentiality for this technology to remove the pollutants from water[32,33] 
4- Installation treatment units in townships that's flow the sewage water in to river directly without any treatment .

5- Replace the old and corroded pipes that's use to distribute water because pipes in general made of mixed of metals especially lead which consider one of the most threatening metal for our daily lives.[34,35,36]

6- Using landscape plants to reduce or to remove the heavy metals depend on many studies conducted by researchers[37,38,39]

7- Studying the other heavy metals which has been not addressed in this research

\section{Acknowledgment}

the authors gratefully acknowledged (MINERAL LABORATORIES,Vancouver,Canada) and (University of Kirkuk-college of science-environmental research unit) .

\section{References}

1. Mulvihill, G. and Pritchard, J. 2010. "McDonald's Recall': 'shrek' Glasses contain Toxic Metal Cadmium', Huffington post,4 June, viewed 24April( 2014).

2. Habayeb A. M.2008. Determination the extent of the agreement between modern paints company waste water and sewage and Iraqi specifications. Al-Taqan journal, 21: A19-A26.

3. Vinodhini, R. and Narayanan, M. 2008. Bioaccumulation of heavy metals in organs of fresh water fish cyprinus carpio (commen carp), Int. Environ. Sci. Teach, 52(1).

4. Afzali D., Taher M.A.,Mostafavi A., Mobarakehs, Z.M. 2005. Thermal modified Kaolinite as useful material for separation and preconcentration of Trace amount of manganese ions. Talanta, $65,476$.

5. Ghaedi M., Fathi M.R., Marahel, f. and Ahmadi F. 2005. Simultaneous Preconcentration and determination of copper nickel, cobalt and lead ions content by flame atomic absorption spectrometer, Fresen .Environ .Bull, 14: 1158.

6. Gebrekidan, A., Gebresellasie, G. and Mulugeta, A. 2009. "Environmental impacts of Shebatannery (Ethiopia) effluents on the surrounding water bodies", Bull. Chem. Soc. Ethiop., J. 23(2): 269.

7. Riadh Adas Abdul Jabar,Shaimaa Fatih Ali ,Tawis Mohammed Kamel. 2013. " Study the presence of some heavy metals in the waters of the Tigris River north of Tikrit the province of Salahdin " Tikrit Journal of Pure Science, 18(2): 123-126.

8. Gunnar Nordberg; Bruce Fowler; Monica Nordberg. Handbook on the toxicology of metals, 4th ed.; Amsterdam, Elsevier, 2014, Chapter 41, Iron. pp 879-902.Website http://dx.doi.org/10.1016/B978-0-444-59453-2.00041 (accessed October 20, (2017)

9. Fawell, J.K., Land, U. and Mintz, B. 2003. Iron in Drinking water. Back ground document for development of WHO Guidelines for DrinkingWater Quality. (online); Geneva. http://www.who.int/water_sanitation_health/dwq/chemicals/iron.pdf (accessed on October 9 , (2017)

10. Ibrahim A.Q., Onyenekwe P.C. and Nwaedozic I.M. 2017. An Efficiency Assessment of Lower Usuma Water Treatment Plant in AbujaMetropolis, Nigeria. Environ. Sci. Toxicol. Food Technol. [Online] 2014, 8, Ver.II., pp 46-53 http://www.scribd.com/document/250619321/ (accessed October 16.

11. Bagheri, H., Afkhami, A., Shirzadmehr, A., Khoshsafar, H. and Ghaedi, H. 2012. Novelpotentiometric sensor for the determination of $\mathrm{Cd} 2+$ based on a new nano-composite. Int $J$ Environ Anal Chem, doi:10.1080/03067 319.(2011).6497 41

12. Wang, K., Zhao, J., Li, H., Zhang, X. and Shi, H. J. 2016. Taiwan Inst. Chem. Eng., 287-291.

13. Rainio, M., Eeva, T., Lilley, T., Stauffer, J. and Ruuskanen, S. 2015. Comp Biochem. Physiol. C. Pharmacol. Toxicol. Endocrinol., 167, 24.

14. Jinlong, Y., Guixiang, Q. and Cheng, D. 2013. Procedia Environ. Sci., 18, 78.

15. Mortimer, J.A., Borenstein, A.R. and Nelson, L. M. 2012. Associations of welding and manganese exposure with Parkinson disease: Review and meta-analysis Neurology 79: 11741180 .

16. Kostova, D. 2010. Determination of manganese by a new spectrophotometry method using toluidine blue. Journal of analytical chemistry, 65: 159-163.

17. Qin, B., Luo, H., Liu, G., Zhang, R., Chen, S., Hou, Y. and Luo, Y. 2012. Nickel ion removal from wastewater using the microbial electrolysis cell, Bioresour. Technol. 121 (2012): 458-461. 
18. Bhatnagar, A. and Minocha, A.K. 2010. Biosorption optimization of nickel removal from water using Punica granatum peel waste, Colloid Surface B. 76 (2010): 544-548

19. Fay, Philip A. 2009. "Precipitation variability and primary productivity in water-limited ecosystems: how plants 'leverage'precipitation to 'finance'growth" Newphytologist, 181(1): 5.

20. Roudan Abdullah Saleh. 2010. "evaluation study of water treatment at kirkuk unified water supply project" Technical. J. n 1 .

21. USEPA.Technical Standard Operation Procedure.SOP EH-01.Adapted from ERT/REAC SOP 2013, Rev. 1. Washington,DC,USA.(2003).

22. World Health Organization (WHO). 2017. Guidelines For Drinking water Quality. $4^{\text {th }}$ edition, incorporating the first addendum.Brazil,World Health Oganization.

23. U.S Enviromental Protection Agency (U.S EPA), 2017. Regional Screening Level (RSL) Summery Table.Online available at http://www.epa.gov/risk/regional-screening-levels-rsisgeneric-tables-june-2017.

24. Dissanayake C.B. and Chandrajith R. 2009. "Introduction to Medical Geology Focus on tropical environments" Springer-Verlag Berlin Heidelberg.305 p.

25. Naveedullah ${ }^{1}$, Muhammad Zaffar Hashmi ${ }^{1}$, Chunna $\mathrm{Yu}^{2}$, Hui Shen ${ }^{1}$, Dechao Duan ${ }^{1}$, Chaofeng Shen ${ }^{1}$, Liping Lou ${ }^{1}$, Yingxu Chen ${ }^{1}$ 2014. "Concentrations and Human Health Risk Assessment of Selected Heavy Metals in Surface Water of the Siling Reservoir Watershed in Zhejiang Province, China" Pol.J.Environ.Stud. 23(3): 801-811.

26. Wongsasuluk, P., Chotpantarat, S. and Siriwong, W. 2011."Human health risk assessment associated with arsenic (as) in drinking shallow ground water wells at Ubon Ratchathani Province, Thailand".2011 2nd International Conference on Environmental Science and Technology, IPCBEE vol.6, (2011) IACSIT Press, Singapore.

27. Naveedullah1, Muhammad Zaffar Hashmi1, Chunna Yu2, Hui Shen1, Dechao Duan1, Chaofeng Shen $1^{*}$, Liping Lou1, Yingxu Chen1"concentration and human health risk assessment of selected heavy metals in surface water of the siling reservoir watershed in zhejiang province, china" pol.J. Environ.Stud. 23(3): 801-811.

28. U.S. Environmental Protection Agency (U.SEPA),(1989).Risk Assessment Guidance for Superfund Volume: Human Health Evaluation Manual (partA).office of Emergency and Remedial Response:Washington D.C,USA.

29. WHO. 2004. Guidelines for Drinking-Water Quality, third ed., Vol.1.Recommendations-World Health Organization, Geneva.

30. Candeias C., da Silva E.F., Avila P.F. and Teixeira J.P. 2014. "Identifying Sources and Assessing Potential Risk of Exposure to Heavy Metals and Hazardous Materials in Mining Areas: The Case Study of Panasqueira Mine (Central Portugal) as an Example" Geosciences, 4: 240-268.

31. Stihi, C.,Radulescus, C., Busuioc, G., Popescu, I.V.,Gheboianu, A. 2011. Ene.Rom.Journ.phys., 56(1-2): 257-264.

32. Fay, Philip A. 2009. "Precipitation variability and primary productivity in water-limited ecosystems: how plants 'leverage'precipitation to 'finance'growth" New phytologist, 181(1): 5.

33. Santafé-Moros, A., J.M. Gozálvez-Zafrilla, J. 2008. Lora-García. Applicability of the DSPM with dielectric exclusion to a high rejection nanofiltration membrane in the separation of nitrate solutions. Desalination, 221: 268-276.

34. Amouha, M. A., Bidhendi, G.R.N. and Hooshyari, B. 2011. Nanofiltration Efficiency in Nitrate Removal from Groundwater: A Semi-Industrial Case Study. 2nd International Conference on Environmental Engineering and Applications IPCBEE vol. 17, IACSIT Press, Singapore.

35. Wang, Y., Han, J., Liu, Y., Wang, L., Ni, L. and Tang, X. 2016. Food Chem, 1130-1136

36. Pourreza, N. and Naghdi, T. J. 2014. Ind. Eng. Chem., 5: 3502-3506

37. Behbahani, M., Ghareh Hassanlou, P., Amini, M. M., Omidi, F., Esrafili, A., Farzadkia, M. and Bagheri, A. 2015. Food Chem., 82-88

38. Ilknur Zeren1*, Alican Cesur2, Elnaji A. Ahmaida Saleh3, Mansour Mosii Mohammed Mossi3" Variation of Chlorophyll Amount in Some Landscape Plants: a case study of Rize" JCBPS; Section B; May 2017 - July (2017), 7(3): 807-817.

39. Adedeji, oludare H., Olayinka, oluwafanmilayo O., Oyebanji, felicia F. 2013. "Assessment of Traffic Related Heavy Metals Pollution of Roadside Soils in Emerging Urban Centres in IjebuNorth Area of Ogun State, Nigeria" J. Appl. Sci. Environ. Manage. 17(4): 509-5 